\title{
Discourse on the Position of The Head of Neighborhood in Urban Village Governance in Padangsidimpuan
}

\author{
Halimatus Sahdiyah Harahap ${ }^{1}$, Nita Nurliawati ${ }^{2}$, Rofi' Romadhona Iyoe ${ }^{3}$, Adinda Fathia ${ }^{4}$, Hasna \\ Khairunnisa Astadipura ${ }^{5}$ \\ Politeknik STIA LAN Bandung, Indonesia
}

\{18110293@poltek.stialanbandung.ac.id'1 ,nitanurliawati@poltek.stialanbandung.ac.id², rofi.iyoega@poltek.stialanbandung.ac.id ${ }^{3}$,20110180@poltek.stialanbandung.ac.id ${ }^{4}$, 20110130@poltek.stialanbandung.ac.id $\left.{ }^{5}\right\}$

\begin{abstract}
The Urban Village is a Regency/City regional apparatus domiciled in the subdistrict area, which is chaired by a headman. In the organizational structure, the urban village still has one level of structure under it, namely Neighborhood which is headed by the head of neighborhood. The Head of the neighborhood is an element of implementing operational tasks from the village in the government and society. Refers to the constitution 1945 paragraph 6 regarding regional autonomy that local governments have the right to form other regulations to carry out autonomy and assistant duties, Mayor's Regulation Number 9 of 2021 concerning the Appointment and Dismissal of the Head of neighborhood in Padangsidimpuan City who functions as an assistant to a headman in carrying out government duties, empowerment and community security. In addition, seeing the abolition of several Government Regulations Number 72 of 2005 about Villages and Number 73 of 2005 about Urban Village, it is necessary to make regulations that discuss the position of the Head of neighborhood in the Governance. This study uses descriptive methods with a qualitative approach and research results obtained through interviews, documentation and literature study.
\end{abstract}

Keywords: Analysis; The mayor's Regulation; Task and function

\section{Introduction}

In essence, the 1945 Constitution regulates regional government in Indonesia which includes Provinces, Regencies/Cities, Special Regions, Special Regions, and Customary Law Community Units. However, apart from the five types of regional government, there are still urban village and villages. Regarding the definition of Urban Village, in fact Law Number 32 of 2004 concerning Regional Government does not provide a detailed explanation of urban village, but Article 120 paragraph (2) of the Regional Government Law states that "Regency/city regional apparatuses consist of regional secretariats, legislative secretariats, regional offices, regional technical institutions, sub-districts, and the village." Which further regulation on urban village is regulated by Government Regulation Number 73 of 2005 concerning Urban Village which means that urban village is a Regency/City regional apparatus domiciled in the Subdistrict area. This regulation also states that the urban village is led by a headman. who is under and responsible to the Regent/Mayor through the subdistric head.

In addition, the definition of urban village is different from village. Based on Law Number. 6 of 2014 concerning the Village is a legal community unit that has territorial boundaries that are authorized to regulate and manage government affairs, the interests of the local community 
based on community initiatives, origin rights, and/or traditional rights that are recognized and respected in the system. the government of the Unitary State of the Republic of Indonesia. While the village government is the village head or what is called by another name, assisted by village officials as an element of village administration. Further regulations regarding villages are regulated through Government Regulation Number. 72 of 2005 concerning Villages.

Based on the previous discussion, it can be seen that the village has a fundamental difference with the urban village. as a legal community unit that has autonomy, the village is not a gift from the central government or local government. This is different from the urban village as part of the apparatus in implementing district/city regional autonomy, so that there is a series of regional apparatuses in it, such as the mayor, Legislative, and sub-district head as the apparatus above the headman, as well as the head of the neighborhood as an element of implementing the operational duties of the urban village head in the field of government.

\section{Methods}

The research method used in this study is a descriptive method with a qualitative approach. A method that aims to describe and summarize various conditions, various situations, or various phenomena of social reality that exist in society which are obtained from the perspective of the actors being studied (informants). The locus of this research is in the city of Padangsidimpuan by comparing mayor's regulation with the city of Manado using a literature review. Data collected from the research locus in the form of primary data from interviews and secondary data from the study of documents related to the mayor's regulation regarding the Head of the Neighborhood.

\section{Results}

To find out how the position of the Head of the Neighborhood is in accordance with the Padangsidimpuan Mayor's Regulation and compare it to the Manado Mayor's Regulation using the Bureaucracy theory proposed by Max Weber. Which includes division of labor, organizational structure, division of tasks, supervision to achieve goals.

\section{Division Labor}

This view allows the organization to maximize the capabilities of its members that are specific to the work or task entrusted to them. However, there are weaknesses faced, namely there are difficulties in coordinating the various tasks carried out by each worker, including ensuring the products produced by the organization.

\section{Organizational structure}

The structure of bureaucratic organizations tends to be in the form of a pyramid (top- down pyramidal organization) with one person at the top,

\section{Division of tasks}

Completion of work in bureaucratic organizations is done by dividing some of the supervisor's duties to his subordinates. Bureaucratic organizations do not recommend that supervisors complete their own tasks but delegate some responsibilities to subordinates. This principle is called delegation of authority.

Supervision 
The achievement of goals in bureaucratic organizations is adjusted to the level of supervision carried out by supervisors/managers, namely the ideal number of subordinates who report to him, or called span of control. The higher the span of control, the more difficult the supervisor/manager's ability to manage subordinates will be. However, if it is too small, there will be a shortage of workload.

\section{Discussion}

Distribution of the administrative area of Padangsidimpuan City:

Table 4. Governance of the Head of the Neighborhood in Urban Village Management in Padangsidimpuan City according to Max Weber's Bureaucracy theory

\begin{tabular}{|c|l|c|c|c|}
\hline Number & \multicolumn{1}{|c|}{ Districts } & Urban Village & village & Number of Environments \\
\hline 1 & Southeast Padangsidimpuan & 2 & 16 & 38 \\
\hline 2 & South Padangsidimpuan & 12 & - & 62 \\
\hline 3 & Padangsidimpuan Batunadua & 2 & 13 & 44 \\
\hline 4 & North Padangsidimpuan & 16 & - & 51 \\
\hline 5 & Padangsidimpuan Hutaimbaru & 5 & 5 & 41 \\
\hline 6 & Padangsidimpuan Angkolajulu & - & 8 & 29 \\
\hline
\end{tabular}

Max Weber argues that bureaucracy states, bureaucracy is a system of power, in which the leader (superordinate) exercises control over subordinates (subordinates). The bureaucratic system emphasizes the "discipline" aspect. So that the bureaucracy is considered as a legal system.

In the theory of bureaucracy, Max Weber put forward 4 (four) views, namely:

\subsection{Division Labor}

The environment is part of the urban village working area with certain boundaries and names determined by the mayor. Meanwhile, in carrying out performance in the environmental area, the headman delegates his duties to the Head of the Neighborhood. Based on article 4 of the Padangsidimpuan Mayor's Regulation Number. 10 Rahun 2021 concerning the Main Duties and Functions of the Head of the Neighborhood, the position of the Head of the Neighborhood is as an assistant in carrying out the operational tasks of the urban village. In other words, the Head of the Neighborhood is located under the headman and is responsible to the headman, but not as part of the urban village apparatus.

In this case, the task of the Head of the Neighborhood regulated by article 5 paragraph (1) of the Mayor of Padangsidimpuan Regulation Number. 10 Rahun 2021 concerning the Main Duties and Functions of the Head of the Neighborhood is to assist the Lurah in administering the government.

The functions of the Head of the Neighborhood according to the provisions of Article 5 paragraph (2) of the Mayor of Padangsidimpuan Regulation Number. 10 Rahun 2021 concerning the Main Duties and Functions of the Head of the Neighborhood, namely:

a. Instilling and fostering a sense of community and community unity in the context of strengthening the Unitary State of the Republic of Indonesia;

b. Develop and prepare plans for government, development, and community programs;

c. Develop plans, implement and manage development as well as the use, preservation and development of development results in a participatory manner; 
d. Development of creativity, prevention of delinquency, and drug abuse (narcotics);

e. Carry out regional and community development, including community organizations, as well as youth and sports organizations;

f. Carry out population data collection and other government administration services;

g. Carry out maintenance of security, public order, and harmony of life among citizens;

h. Create and accommodate the aspirations and ideas of the community in the implementation of development by developing aspirations and self-help mutual assistance and community participation in the region;

i. Mobilize self-help mutual assistance and community participation in the region;

j. Supporting communication, information, and socialization media between urban village and the community;

k. Implement, support, and coordinate government activity programs, builders, and empower urban village, sub-district, and city government activities;

1. Carry out community empowerment efforts in supporting the smooth administration of government and development;

m. Carry out efforts to overcome the homeless, beggars, and street children;

n. Carry out control of street vendors;

o. Take an active role in efforts to increase Regional Original Income; and

p. Take an active role in the enforcement of Regional Regulations.

\subsection{Duties, Functions, and Positions of the Head of the Manado City Neighborhood}

The duties, functions and positions of the Head of the city of Manado Neighborhood are discussed in the Regulation of the Mayor of the City of Manado Number. 3 of 2017 the third amendment to the Regulation of the Mayor of Manado Number. 54 of 2014, in Chapter II Article 2 it is stated that the Head of the Neighborhood is tasked with assisting the tasks of the headman in the neighborhood.

Therefore, to carry out this task, the Head of the Neighborhood has the following functions:

a. Carry out population registration;

b. Keeping the environment clean;

c. Doing Implementation government in urban village, empowerment public, society service;

d. Maintenance of peace and public facilities;

e. Data collection, service and implementation of retribution and tax activities;

f. Monitoring and evaluation of development implementation activities; and

g. As a motivator for community empowermen.

\subsection{Structure of the Organization}

The organizational structure of the Padangsidimpuan village as regulated in the Padangsidimpuan City Regional Regulation Number. 7 of 2003 Article 12 states that the organizational structure of the urban village consists of:

Consists of :

a. Headman;

b. Secretary;

c. Government Section;

d. Social Welfare and Development Section; and

e. Environment. 


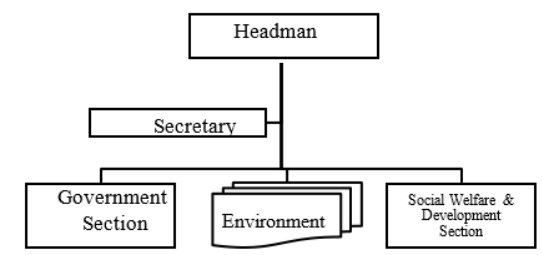

In contrast to the organizational structure of the Manado urban village as regulated in Manado Mayor's Regulation Number 65 of 2016 Article 14 it is stated that the organizational structure.

Consists of :

a. Headman;

b. Secretary;

c. Government Section;

d. Social Welfare and Development

e. Section; and Environment.

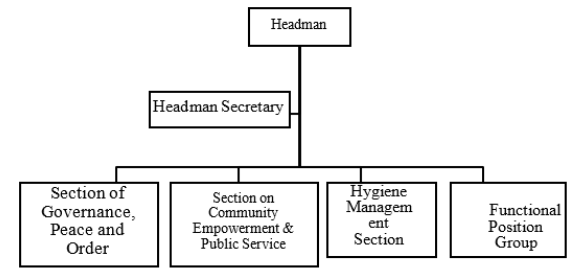

In contrast to the organizational structure of the Manado urban village as regulated in Manado Mayor's Regulation Number 65 of 2016 Article 14 it is stated that the organizational structure.

Consists of:

a. Headman;

b. Headman Secretary;

c. Section of Governance, Peace and Order;

d. Section on Community Empowerment and Public Service Section;

e. Hygiene Management Section;

f. Functional Position Group;

There is a difference between the organizational structure of the urban village of Padangsidimpuan City and the City of Manado, seeing that in the organizational structure of the urban village of Padangsidimpuan City, the environment including the head of the Neighborhood is included in the ranks of the organizational structure of the urban village, in contrast to the organizational structure of the urban village of Manado City where the environment including the head of the neighborhood is not included in the ranks of the structure village organization.

\subsection{Delegation of Authority}

At this point, it can be seen from the systematic organizational structure set by each local government. Where is the delegation of authority that is bottom-up. However, there are differences in the delegation of authority of the Head of the Neighborhood based on mayor's regulation Padangsidimpuan with Perl Manando, namely: 
a. In mayor's regulation Padangsdimpuan that the delegation of authority comes from the urban village directly to the Head of the Neighborhood, this is clear because the Head of the Neighborhood is included in the organizational structure of the Village.

b. Whereas in the Mayor's Regulation in Manado, the Head of the Neighborhood is not directly included in the organizational structure of the village, but in every existing structure where the role of the Head of the Neighborhood is very necessary because the duties and functions of the Head of the Neighborhood include it.

\subsection{Surveillance Effort}

Internal supervision of the performance of the Head of the Padangsidimpuan City Neighborhood is carried out by the headman as the highest leader in the urban village. Where the Head of the Neighborhood must submit a performance report that is carried out, such as population data entering and leaving, this is evidenced by the existence of documents that are filled out by the Head of the Neighborhood every week. In addition, external supervision is also carried out by the community.

That is, the community has an indirect role in assessing the performance of the Head of the Neighborhood. If abuses and prohibited actions are found in accordance with mayor's regulation number 09 of 2016 Padangsidimpuan City, the Head of the Neighborhood will be given sanctions in accordance with his actions ranging from temporary dismissal to revoking his mandate by the subdistric head.

However, this is actually different from the Manado City Mayor's Regulation Number 03 of 2017 which contains Chapter VII on Guidance and Supervision which has a flow that the Guidance of the Head of the Neighborhood is carried out by the Office of Social Affairs and Community Empowerment through the Public Relations of the Manado City Secretariat for administration and Head of the Neighborhood Operations. Then the subdistric head and headman also take part in the nay that every 1 (one) time a month conducts an evaluation of the performance of the Head of the Neighborhood.

LAPORAN KEGINTAN KEBERSIHAN, KEAMANAN DAN

KETERTIBN SERTA PELAYANUN KEPADA MASYARAKAT KEADMN BULAN ..._._....... TAHUN 201

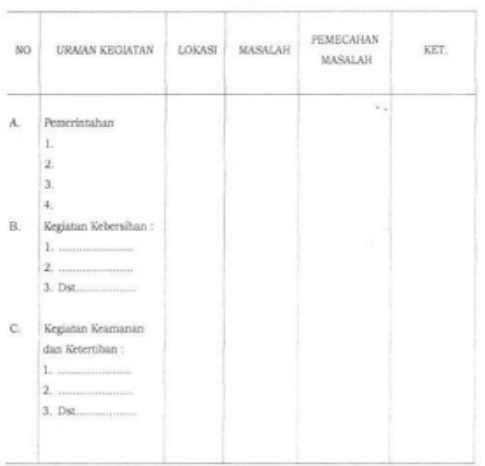

\section{Conclusion}

From the description of the explanation in the section above, it can be seen that the Head of the Neighborhood has an important role in governance at the urban village level. This means that the smallest government in the scope of Padangsidimpuan City is starting from the Head of the Neighborhood. This is because not all tasks and functions that exist in the environment can 
be carried out by the Lurah so that the Head of the Neighborhood is formed as a liaison and assistant for carrying out the headman's duties in the community.

As important as the Head of the Neighborhood is the Regional Head issues their respective regulations regarding the appointment, dismissal and work mechanism of the Head of the Neighborhood which includes the duties and functions of the Head of the Neighborhood. Such as the Padangsidimpuan City Mayor's Regulation Number. 9 of 2016 and Madano City's Mayor's Regulation Number. 03 of 2017.

However, in these two Mayor's Regulation there are differences as explained in the discussion section, such as in the composition section to the substance and clarity of the position of The head of Neighborhood. Therefore, it is necessary for all regions to issue regulations related to the Head of the Neighborhood. This aims to clarify the position of the Head of the Neighborhood which is really needed in the community, and the strong legality of a Head of the Neighborhood so that it has an impact on the responsibilities and performance capacity of the Head of the Neighborhood.

\section{References}

[1] Mayor's regulation of Padangsidimpuan Number 9 of 2016.

[2] Mayor's regulation of Padangsidimpuan Number 10 of 2016.

[3] Mayor's Regulation of Manado Number 3 of 2017.

[4] The constitution UUD 1945

[5] Mulyadi, Dedi. 2018. Studi Kebijakan Publik dan Pelayanan Publik. Bandung: Alfabet. 